\title{
Coupling Between Magmatic Degassing and Volcanic Tremor in Basaltic Volcanism
}

\section{Giuseppe G. Salerno ${ }^{*}$, Mike Burton ${ }^{2}$, Giuseppe Di Grazia' ${ }^{1}$, Tommaso Caltabiano ${ }^{1}$ and Clive Oppenheimer ${ }^{3}$}

${ }^{1}$ Istituto Nazionale di Geofisica e Vulcanologia, Osservatorio Etneo, Sezione di Catania, Catania, Italy, ${ }^{2}$ School of Earth, Atmospheric and Environmental Sciences, University of Manchester, Manchester, United Kingdom, ${ }^{3}$ Department of Geography, University of Cambridge, Cambridge, United Kingdom

Magmatic degassing, typically measured as $\mathrm{SO}_{2}$ flux, plays a fundamental role in controlling volcanic eruption style and is one of the key parameters used by volcano observatories to assess volcanic unrest and detect eruption precursors. Volcanic tremor, the integrated amplitude of seismic energy release over a range of frequencies, is also a key parameter in volcano monitoring. A connection between volcanic degassing and tremor has been inferred through correlations between the signals which are often, but not always, observed during periods of unrest or eruption. However, data are often equivocal and our understanding of the physical processes, which couple degassing with tremor are still evolving. New insights into degassing-tremor coupling can be made by investigation of the long-term relationship between degassing and tremor, focusing on the frequency-dependence of tremor and passive degassing behavior. In this study, we examine how long-term $\mathrm{SO}_{2}$ emission rates and volcanic tremor on Mt. Etna, track rapid variability in eruptive dynamics. Correlations between $\mathrm{SO}_{2}$ flux and tremor are explored in both quiescent and eruptive periods, comparing the two parameters at both long and short time-scales ( $<<1$ day) for $\sim 2$ years. Our analysis reveals that over $\sim$ month-long timescales passive degassing of $\mathrm{SO}_{2}$ and tremor tend to be well-correlated, but these correlations are lost over shorter timescales. This reflects a coupling process between passive degassing and tremor, produced by a combination of gas flow through permeable magma and the convective flow of magma within the conduit. Short-term correlations are lost because variations in the continuous degassing process are relatively small compared with the overall degassing rate and fall below measurement noise. During eruptive periods strong correlations are observed between degassing and tremor, with a significant contribution of higher frequency signal in tremor, controlled by eruptive style. These observations suggest that in syneruptive periods the tremor source is dominated by the coupling between the eruption column and the ground through infrasonic waves, rather than conduit processes. Our results demonstrate the importance of high quality long-term observations and offer new insights into the physical mechanisms which couple degassing and volcanic tremor at active volcanoes.

Keywords: Mt. Etna, $\mathrm{SO}_{2}$ flux, volcanic tremor, eruptive and quiescent degassing, volcano monitoring 


\section{INTRODUCTION}

Over the last decades, technological advances have allowed volcanic activity to be monitored at ever-increasing spatial and temporal resolutions (e.g., Heliker et al., 2003; Calvari et al., 2008; Johnson and Poland, 2013). Particularly, in the case of volcanic ground-based gas measurements the development of automated networks of spectrometer gas sensors (e.g., Edmonds et al., 2003a; Salerno et al., 2009b), ultraviolet and thermal cameras (e.g., Mori and Burton, 2006; Burton et al., 2015a; Lopez et al., 2015), and FTIR and multigas sensors (e.g., Burton et al., 2003; Shinohara, 2005; Taquet et al., 2017), have improved the temporal resolution of magmatic gas composition and flux observations, e.g., $\mathrm{SO}_{2}$ flux, from typically of order hours to $\sim 1 \mathrm{~Hz}$. This has permitted comparison with geophysical measurements, thus allowing better integration of both geochemical and geophysical parameters for refining models and to identify eruptive anomalies and unrest (e.g., Aiuppa et al., 2010; Bonaccorso et al., 2011b; Poland et al., 2012; Patanè et al., 2013; Burton et al., 2015b; Hibert et al., 2015; Nadeau et al., 2015). In particular, volcanic $\mathrm{SO}_{2}$ emissions are important indicators of subsurface processes, and the study of their temporal evolution provides inferences on processes occurring at shallow depth ( $\sim 4-5 \mathrm{~km}$ from crater top). Measurements of $\mathrm{SO}_{2}$ emissions made over almost 40 years (e.g., Williams-Jones et al., 2008), have shown remarkable transitions from quiescence to unrest at both silicic magmatic systems (e.g., Fischer et al., 1994; Williams-Jones et al., 2001; Nadeau et al., 2011) and mafic volcanoes (e.g., Malinconico, 1979; Voight et al., 1999; Sutton et al., 2001; Caltabiano et al., 2004; Kazahaya et al., 2004). Measurement of $\mathrm{SO}_{2}$ outgassing also provide constraints on magma-degassing budgets and mass balance (e.g., Wallace and Gerlach, 1994; Allard, 1997; Shinohara, 2008; Steffke et al., 2011).

Volcanic tremor is observed at volcanoes as background seismic radiation in quiescent stages and as peaks in amplitudes during eruptive episodes such as explosive eruptions (e.g., Alparone et al., 2003; Patanè et al., 2013). Dominant frequency ranges between 0.1 and $10 \mathrm{~Hz}$ and episodes of high amplitude tremor may persist for months (e.g., Kubotera, 1974; McNutt, 1992; Zobin, 2003). Physical processes generating volcanic tremor are thought to be associated with unsteady mass transport-flow of magma dynamically coupled with the surrounding rocks (Steinberg and Steinberg, 1975; Schick and Mugiono, 1991; Neuberg and Pointer, 2000; Battaglia et al., 2005). However, several other mechanisms (e.g., Gordeev, 1993; Benoit and McNutt, 1997) and models have been proposed as potential sources of tremor (e.g., Aki et al., 1977; Chouet et al., 1987) depending on individual volcanoes and eruption style (Konstantinou and Schlindwein, 2002; Matoza and Fee, 2014). In particular, a review of the engineering literature associated with studies of two phase fluid flow induced vibration in pipes was recently published (Miwa et al., 2015), focusing on the hydrodynamic force produced by flows that generate potentially destructive vibrations in industrial machines and infrastructure. The review highlighted the impact of different flow patterns, turbulence and pipe geometry, producing a fluctuation force magnitude spectrum with a frequency range similar to that observed for tremor in volcanic settings when velocities were in the range of magma flow during quiescent degassing $\sim 0.6 \mathrm{~ms}^{-1}$ (Burton et al., 2007).

Persistent degassing from active volcanoes is widely associated with volcanic tremor (e.g., Williams-Jones et al., 2001; Konstantinou and Schlindwein, 2002; McNutt, 2002). Evidence of coupling between the two parameters has been discussed at different volcanic systems (e.g., Mt. Etna: Gresta et al., 1991, Bruno et al., 1995; Patanè et al., 2013; Zuccarello et al., 2013; Soufrière Hills: Miller et al., 1998; Edmonds et al., 2003b; Piton de la Fournaise: Battaglia et al., 2005; Colima: VargasBracamontes et al., 2009). Increases in tremor amplitude were observed prior to and during effusive eruptions and synchronous with explosive activity (e.g., Usu: Omori, 1911; Pavlof: McNutt, 1986; Hekla: Brandsdóttir and Einarsson, 1992; Galeras: Fischer et al., 1994; Mt. Etna: Cannata et al., 2008; Bonaccorso et al., 2011b; Kilauea: Nadeau et al., 2015). Changes in the dominant tremor frequency have been commonly associated with changes in the regime and style of eruptive activity (e.g., Ereditato and Luongo, 1994; Thompson et al., 2002; Alparone et al., 2003; Bryan and Sherburn, 2003; Cannata et al., 2018). At Mt. Etna, Leonardi et al. (2000a) studied the relationship between volcanic tremor and $\mathrm{SO}_{2}$ flux in the period between 1987 and 1992 by cross-correlation analysis. Their results indicated that, in the case of eruptive activity, the two signals strongly correlated. The authors proposed that such as behavior might have resulted from common physical mechanisms related to magma dynamics. Similarly, at Soufrière Hills, Montserrat, Young et al. (2003) found systematic and direct correlation between $\mathrm{SO}_{2}$ flux and tremor analyzing data between December 1999 and January 2000, with gas flux lagging behind the tremor signal. Similar correlations between $\mathrm{SO}_{2}$ outgassing and seismic amplitude were observed also at Villarrica (Palma et al., 2008), Yasur (Bani and Lardy, 2007), Fuego (Nadeau et al., 2011), and Kilauea (Nadeau et al., 2015). Volcanic tremor has also shown good correlation with other geochemical parameters. For instance, Alparone et al. (2005) carried out a statistical analysis on radon emissions from the soil and reduced displacement of volcanic tremor both recorded during paroxysmal explosive phases of Mt. Etna's summit craters. Their studies revealed increase in radon concentrations $\sim 58 \pm 12 \mathrm{~h}$ prior to changes in volcanic tremor. More recently, investigating the relationship between $\mathrm{CO}_{2}$ flux and volcanic tremor at Mt. Etna, Cannata et al. (2009a) found that variations in the geochemical signal preceded those of volcanic tremor of $\sim 50$ days. Nevertheless, in some cases contradictory or/and lack of relationship between eruptive activity and tremor amplitude has been observed. Doukas and Gerlach (1995), observed an episode of inverse correlation between $\mathrm{SO}_{2}$ flux and volcanic tremor at Mount Spurr, Alaska during the 1991-1993 eruptive activity, interpreting the gas declined as a result of $\mathrm{SO}_{2}$ absorption by the hydrothermal system. Similarly, inverse correlations between $\mathrm{CO}_{2}$ flux and volcanic tremor were observed at Stromboli (Aiuppa et al., 2009). At Soufrière hills volcano, Watson et al. (2000) reported that high rates of $\mathrm{SO}_{2}$ were associated with enhanced seismicity and ground deformation a month before the 1997 dome collapse. However, previous observations by Young et al. (1998) showed 
that the enhanced long-period seismicity at Soufrière Hills did not relate to increases in $\mathrm{SO}_{2}$ flux. This indicates that, though tremor and degassing are somewhat coupled, the nature of their relationship, as well as the source mechanism for tremor, are still poorly understood. It is likely that several processes are involved in the generation of volcanic tremor from gas and magma flows, making the unraveling of the tremor and degassing relationship challenging.

Here, we focus on three mechanisms by which volcanic tremor may be coupled with degassing: (1) flow of gas through permeable magma (e.g., Burton et al., 2007; La Spina et al., 2017), (2) magma flow within a conduit (e.g., Kazahaya et al., 1994; Beckett et al., 2014), and (3) coupling of eruptive processes to ground seismicity through infrasound during explosive activity (Matoza and Fee, 2014). The links between these processes and magmatic degassing are explored on Mt. Etna by comparing seismic tremor measured with the INGV seismic network with $\mathrm{SO}_{2}$ flux measurements collected with INGV FLAME network. Long- and short-timescale comparisons of the two parameters for six case studies selected between 2007 and 2008 were carried out by correlation analysis to investigate whether the correlation holds across different timescales.

\section{ERUPTIVE ACTIVITY BETWEEN 2007 AND 2008}

Mt. Etna is the most active volcano in Europe characterized by extensive quiescent and active degassing activity that occurs at the main craters (North-East Crater: NEC, South-East Crater: SEC, and central craters Voragine: VOR, and Bocca Nuova: BN, Figure 1; e.g., Allard, 1997; Aiuppa et al., 2008). Between 2007 and 2008, eruptive activity at Mt. Etna resumed after a quiescent period following the 2006 eruption (Bonaccorso et al., 2011a). Activity was vigorous and characterized by a series of relatively short explosive episodes and long-lasting lava effusion both occurring from the eastern flank of SEC. (Andronico et al., 2008; Corsaro and Miraglia, 2009; Bonaccorso et al., 2011a). This period is divided into two main phases, firstly the period January 2007 to early May 2008 characterized by intermittent lava fountains and the period May-December 2008, characterized by effusive activity (Figure 2). The first stage, from January 2007 to early May 2008, consisted of sporadic violent strombolian and lava fountaining episodes accompanied by short-lasting lava effusion (e.g., Andronico et al., 2008; Di Grazia et al., 2009; Bonaccorso et al., 2011a,b; Behncke et al., 2016). Paroxysms exhibited recurrent features consisting on increasing strombolian activity at first, lava flow output, and transition from strombolian to lava fountaining (Aloisi et al., 2009; Di Grazia et al., 2009; Langer et al., 2010). This activity was similar to the lava fountain sequences observed at SEC in 2000 (e.g., Alparone et al., 2003; Allard et al., 2005; La Spina et al., 2015), and between 2011 and 2015 (e.g., Calvari et al., 2011; Patanè et al., 2013; Corsaro et al., 2017). The effusion phase, between 13 May and December 2008, started 3 days after the 10 May paroxysm (Aloisi et al., 2009; James et al., 2011), and was dominated by lava effusion occasionally accompanied between May and early September
2008 with strombolian activity from the eruptive fissure (Cannata et al., 2009b; Bonaccorso et al., 2011a; Currenti et al., 2011).

\section{DATA ACQUISITION AND ANALYSIS}

All data presented here were acquired by the continuous geochemical and geophysical monitoring system of Istituto Nazionale di Geofisica e Vulcanologia, Osservatorio Etneo (INGV-OE).

\section{$\mathrm{SO}_{2}$ Flux}

The bulk $\mathrm{SO}_{2}$ flux from the summit craters and eruptive fissure of Mt. Etna was measured automatically by the FLAME scanning spectrometer network (Salerno et al., 2009b; Calvari et al., 2011). The network consists of ten ultraviolet scanning spectrometer stations spaced $\sim 7 \mathrm{~km}$ apart and installed at an altitude of $\sim 900 \mathrm{~m}$ above sea level (a.s.l.) on the flanks of Mt. Etna (Calvari et al., 2011). Recorded UV spectra were retrieved in $\mathrm{SO}_{2}$ column amounts using the DOAS method (e.g., Platt and Stutz, 2008), and applying a modeled background reference spectrum (Burton et al., 2009; Salerno et al., 2009a). Retrieved $\mathrm{SO}_{2}$ data were transmitted to INGV-OE where they were converted into mass flux rate. Each flux datum was time corrected to account for the travel time of the plume from the summit craters to the scanning plane of each scanner of the network $(\sim 14 \mathrm{~km})$. Uncertainty in computed $\mathrm{SO}_{2}$ flux depends to an extent on plume velocity, because at very low velocities the absolute velocity error becomes a larger proportion of the relative error in calculated flux. Assumptions on plume height are made based on observations of the relationship between plume velocity and height, and light scattering effects also contribute to the flux error budget (e.g., Mori et al., 2006; Campion et al., 2015). Salerno et al. (2009b) estimates uncertainty in $\mathrm{SO}_{2}$ flux by stationary automatic scanning array between $-22+36 \%$, but error can vary to greater than $100 \%$ depending on conditions.

\section{Seismic Data}

The permanent seismic network of INGV comprises 45 threecomponent broadband (40 s) digital stations with continuous data acquisition and transmission at a sampling frequency of $100 \mathrm{~Hz}$ (Figure 1; e.g., Di Grazia et al., 2006; Patanè et al., 2008). In this work, we use data from the Etna Cratere del Piano (ECPN) station, which is set up on the southern flank of the volcano at an altitude of $2900 \mathrm{~m}$ a.s.l. and $\sim 1 \mathrm{~km}$ from the summit craters (Figure 1). The ECPN station was chosen as it offers the longest data continuity provided during the studied period, the best signal to noise ratio and its proximity to the summit craters makes it especially sensitive to eruptive activity. Volcanic tremor spectral amplitude was calculated using the root mean square (RMS expressed in arbitrary unit) of the seismic signal recorded on the vertical component. In this study, the daily RMS at overall spectral amplitude (OSA) was used for long-term characterization of volcanic tremor and to explore its relationship with daily $\mathrm{SO}_{2}$ flux. In order to inspect the shortterm relationship between $\mathrm{SO}_{2}$ flux and tremor and identify if any and which frequency components correlated most strongly with 


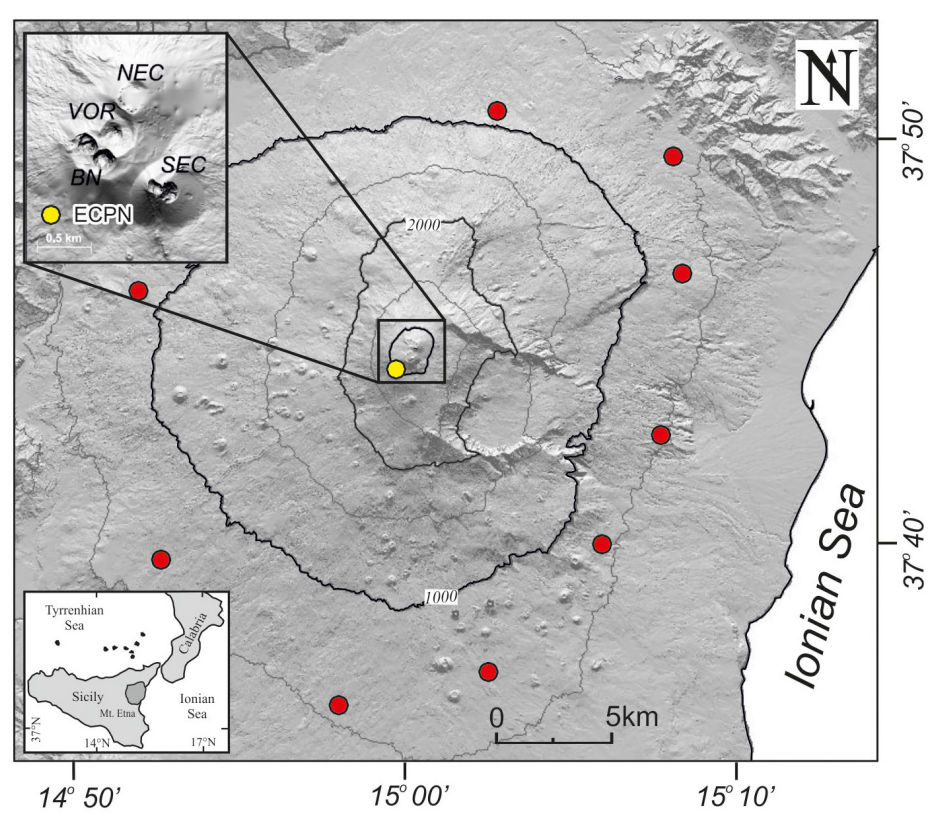

FIGURE 1 | Map of Mt. Etna with location of the FLAME scanning spectrometers network (red-solid circles) and the Etna Cratere del Piano (ECPN) seismic station used for this study (yellow-solid circle). The shaded relief on the upper left corner details the volcano four-summit craters (VOR, BN, SEC, and NEC) and the ECPN station. In the bottom left is showed the geographic location of Mt. Etna and Sicily.

degassing rates, seismic amplitude was decomposed into separate frequency bands (e.g., Gresta et al., 1987; Thompson et al., 2002; Di Grazia et al., 2009). RMS spectral amplitude was calculated for several frequency bands of $1 \mathrm{~Hz}$ width in the frequency range $0.025-10.5 \mathrm{~Hz}$, and tremor amplitude was obtained by averaging the RMS values with a 5 min time window. This time window was chosen according Cannata et al. (2009a), who report that time windows of this length are a good compromise between the stability of the signal and the opportunity of observing details of the evolution of the parameter during eruptions. Uncertainties affecting RMS depends on the dispersion of the averaged RMS time window; it ranges between $10 \%$ for the short- 5 min intraday study and up to mean $25 \%$, enveloped between a minimum of $6 \%$ and maximum of 77\%, for the long-temporal daily averaged RMS.

\section{Data Analysis}

To investigate the relationship between the $\mathrm{SO}_{2}$ flux and volcanic tremor, we apply the correlation analysis, which expresses the strength of linkage or co-occurrence between two variables in a single value ranging from -1 to +1 , i.e., $-1 \leq \mathrm{r} \leq+1$ (e.g., Davis, 1986; McKillup and Dyar, 2010). Usually for evaluating dependences between two parameters, the conventional Pearson's correlation analysis is used. However, this method requires normal distribution of the parameter samples. Since both $\mathrm{SO}_{2}$ flux and volcanic tremor data were characterized by nonGaussian distribution (mean skewness and kurtosis are 1.1 and 0.9 , and 1.2 and 1.1, respectively; Table 1 and Supplementary Figure S1) and the $\mathrm{SO}_{2}$ flux sample sizes were small (maximum 120 daily-light observations), the non-parametric Spearman's Rank correlation analysis was applied (e.g., Zar, 1972; Davis,
1986; Swan and Sandilands, 1995). Compared to the Pearson's correlation analysis, the Spearman's correlation method does not require continuous-level data (interval or ratio), as it uses ranks instead of assumptions on the distributions of two variables. This allows analysis of the association between variables of ordinal measurement levels. Mathematically, Spearman's and Pearson's correlations are very similar in the way that they use different measurements to calculate the strength of association of two parameters. Pearson's correlation applies standard deviations, while Spearman's the difference in ranks (Davis, 1986; Swan and Sandilands, 1995).

\section{RESULTS}

Figure 2 reports the weekly averaged $\mathrm{SO}_{2}$ flux and the daily OSA of the volcanic tremor RMS for long-term observation between 2007 and 2008. Over the investigated period, tremor and $\mathrm{SO}_{2}$ flux show common changes at different temporal and magnitude scales associated in both stages of quiescentpassive degassing and eruptive activity (Figure 2). During the intermittent paroxysmal phase, preceding the opening of the eruptive fissure on May 13, 2008, the $\mathrm{SO}_{2}$ rates and tremor behaved in a similar manner showing marked oscillations in correspondence to the explosive activity. These waxing-waning trends have higher amplitudes starting from the end of July 2007 until the opening of the 2008-2009 eruptive fissure (Table 1). Note that in Figure 2, volcanic tremor RMS is plotted in logarithmic scale to allow for better comparison with $\mathrm{SO}_{2}$ flux, and values are expressed in arbitrary units. Short-term intraday comparison between $\mathrm{SO}_{2}$ flux-volcanic tremor patterns were 


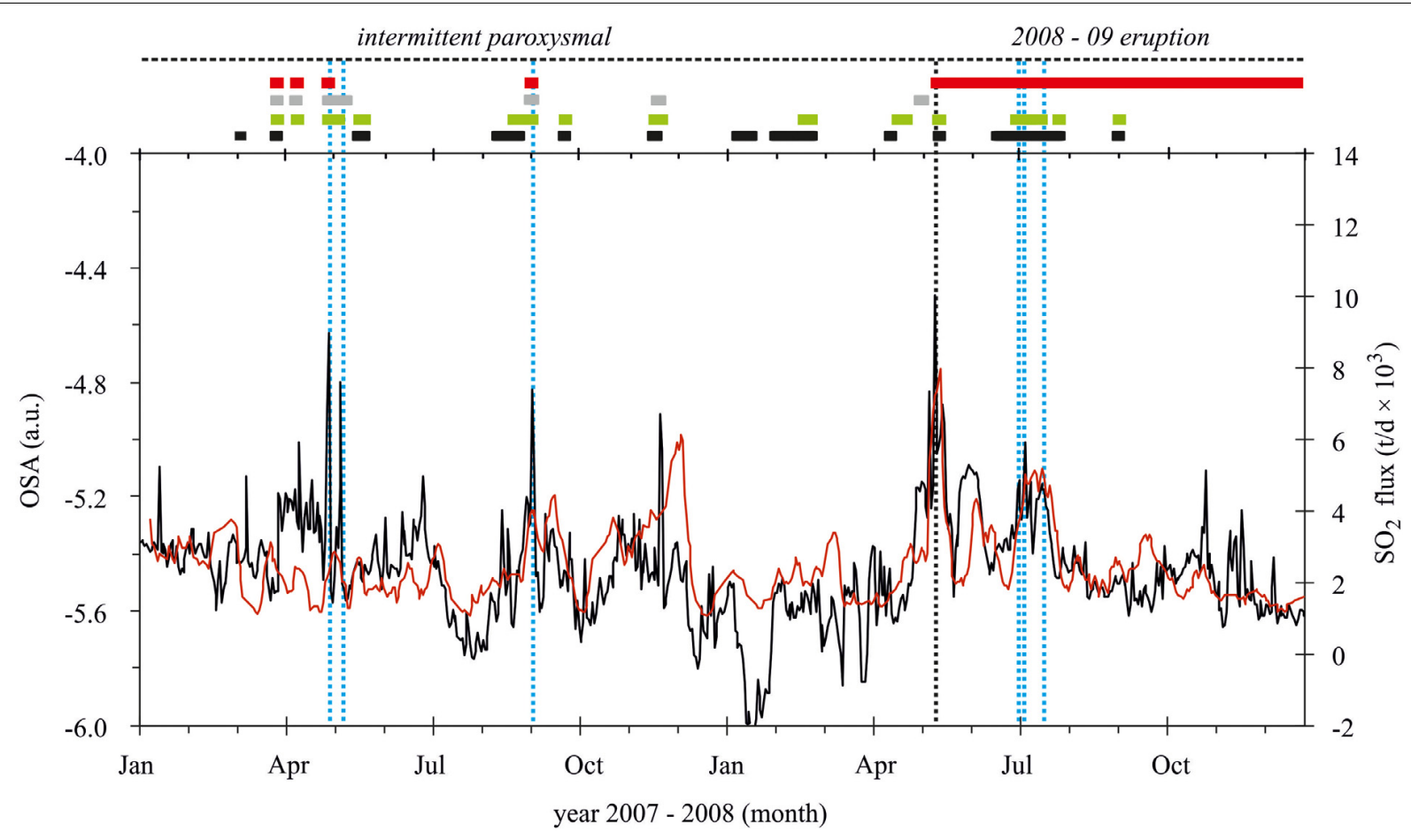

FIGURE 2 | Weekly averaged $\mathrm{SO}_{2}$ flux (in red) and daily averaged overall spectral amplitude (OSA) of the volcanic tremor (in black) in 2007 and 2008 ; tremor is represented on a logarithmic. The black-dashed vertical line between April and July 2008 indicates the start of the $2008-09$ eruptive activity on 13 May while the blue-dashed lines indicate the selected case studies explored at intraday scale. The upper graph shows the summary of the eruptive activity of Mt. Etna in the studied period. The 2-year long time window can be splitted into two phases according to the eruptive activity observed at the surface. The first phase relates to an intermittent paroxysmal phase consisting of ash emission (black square), strombolian activity (green-square), lava fountaining (gray-square), and lava emission (red-square), the second phase refer to a period characterized by persistent lava emission and irregular moderate strombolian explosions and ash emissions along the 2008-09 eruptive fissure. Uncertainty in $\mathrm{SO}_{2}$ flux by stationary array arise from several sources, such as wind-plume transport speed, plume height and radiative transfer, these parameters maybe highly variable being the flux affected by and uncertainty that may ranges between -22 and 36 , up to $100 \%$ in challenging condition. Uncertainty in daily RMS depends on the intraday variability of the seismic averaged signal and it ranges between $10 \%$ for the intraday study and mean of $25 \%$ for the daily long-term investigation.

carried out to explore potential correlation between the two signals on a scale of minutes (Figure 3). Of the seven lava fountain episodes of the intermittent paroxysmal phase and of the strombolian activity fed by the eruptive fissure on 14 May, only 6 days could be analyzed (Table 1). The other episodes had to be excluded due to eruptive events at night (when UV spectroscopy was not possible) or on days when the plume was blown to the northern and western flanks of the volcano beyond the coverage of the FLAME network. In addition, some of the eruptive episodes were also excluded from the analysis due to the limited number of $\mathrm{SO}_{2}$ scans on the given days.

Figure 3 shows the intraday $\mathrm{SO}_{2}$ flux and volcanic tremor data for the six case studies. In each of the six graphs, $\mathrm{SO}_{2}$ flux is plotted together with RMS at a dominant frequency, i.e., that has shown the highest $\mathrm{SO}_{2}$ flux-volcanic tremor correlation coefficient between 0.025 and $10.5 \mathrm{~Hz}$; likewise correlation analysis was also performed considering the OSA (Table 1; Figure 4). Signals display simultaneous changes in both magnitude and temporal scale repeatedly over the course of the measurements and persist over time scales ranging from 6 to $12 \mathrm{~h}$. This correlation occurs during both stage of onset and waning phase of strombolian activity (case 1 and 2) and transition from strombolian to lava fountaining (case 3 ), both eruptive styles superimposed on short-lived and persistent lava flow output (46; Table 1). $\mathrm{SO}_{2}$ flux was strongly correlated with seismic tremor between 2.5 and $6.5 \mathrm{~Hz}$ during explosive eruptions and between 0.025 and $2.5 \mathrm{~Hz}$ (case studies 1-3, and in 4-6, respectively; Table 1), isolated anticorrelation were also observed for cases 1, 2, and 4 , when $\mathrm{SO}_{2}$ emission rates increased while RMS decreased.

\section{DISCUSSION}

From these observations, we see that in both the initial period between January 2007-May 2008 and the effusive eruption from May 2008 onwards, a strong correlation is observed between tremor and the weekly averaged $\mathrm{SO}_{2}$ flux (Figure 2). We highlight in particular the quiet eruptive period between May and December 2007, when the relationship between tremor and $\mathrm{SO}_{2}$ flux is marked, and a further period of close correlation is observed between May and December 2008, associated with the effusive eruption. We propose that this arises from a driving mechanism of magma flow, in which seismic energy is produced through friction between the flowing magma and conduit walls. 
TABLE 1 | Details of the main features and parameters of the intermittent paroxysmal and eruptive 2008-2009 phases and of the six case studies investigated.

\begin{tabular}{|c|c|c|c|c|c|c|}
\hline Phase & Parameter & Min & Max & Mean & $\delta$ & \\
\hline \multirow[t]{2}{*}{ Intermittent paroxysmal } & $\Phi \mathrm{SO}_{2}$ & 400 & 13,500 & 2400 & 1500 & \\
\hline & $V t$ & -6.0 & -4.6 & -5.5 & 0.2 & \\
\hline \multirow[t]{2}{*}{ Eruption 2008-2009 } & $\Phi \mathrm{SO}_{2}$ & 450 & 20,000 & 2700 & 650 & \\
\hline & $V t$ & -5.7 & -4.5 & -5.4 & 0.2 & \\
\hline Case study & 1 & 2 & 3 & 4 & 5 & 6 \\
\hline Date & April 29, 2007 & May 07, 2007 & September 04, 2007 & July 07, 2008 & July 10, 2008 & July 24, 2008 \\
\hline Eruptive style & explosive & explosive & explosive & effusive - explosive & effusive - mild explosive & effusive-mild explosive \\
\hline Frequency band $V t(\mathrm{~Hz})$ & $5.5-6.5$ & $5.5-6.5$ & $2.5-3.5$ & $0.025-0.5$ & $1.5-2.5$ & $0.5-1.5$ \\
\hline$\rho$ & 0.0 .7 & 0.9 & 0.7 & 0.6 & 0.8 & 0.6 \\
\hline $\operatorname{Min} \Phi \mathrm{SO}_{2}$ & 700 & 1300 & 1300 & 2100 & 1100 & 750 \\
\hline $\operatorname{Max} \Phi \mathrm{SO}_{2}$ & 20,000 & 13,000 & 10,000 & 11,000 & 17,000 & 10,300 \\
\hline Mean $\Phi \mathrm{SO}_{2}$ & 5600 & 6000 & 3500 & 5500 & 7500 & 2600 \\
\hline$\delta \Phi \mathrm{SO}_{2}$ & 4500 & 3700 & 1500 & 2500 & 4100 & 1950 \\
\hline Min Vt & $4.0 \times 10^{-7}$ & $7.2 \times 10^{-7}$ & $4.2 \times 10^{-6}$ & $1.9 \times 10^{-7}$ & $1.4 \times 10^{-6}$ & $8.8 \times 10^{-7}$ \\
\hline Max Vt & $1.8 \times 10^{-5}$ & $2.8 \times 10^{-5}$ & $1.5 \times 10^{-5}$ & $3.3 \times 10^{-7}$ & $3.6 \times 10^{-6}$ & $1.9 \times 10^{-6}$ \\
\hline Mean Vt & $5.3 \times 10^{-6}$ & $9.2 \times 10^{-6}$ & $7.1 \times 10^{-6}$ & $2.4 \times 10^{-7}$ & $2.1 \times 10^{-6}$ & $1.1 \times 10^{-6}$ \\
\hline$d V t$ & $3.0 \times 10^{-6}$ & $1.1 \times 10^{-5}$ & $2.5 \times 10^{-6}$ & $2.6 \times 10^{-8}$ & $4.9 \times 10^{-7}$ & $1.8 \times 10^{-7}$ \\
\hline
\end{tabular}

Results of the tremor frequency bands with maximum correlation used in this study together with statistical details on the $\mathrm{SO}_{2}$ emission rate and volcanic tremor.

Analysis of the source depth of seismic tremor demonstrates that the entire shallow conduit is a tremor source (e.g., Patanè et al., 2008; Cannata et al., 2013), consistent with our frictional flow hypothesis, with a peak in energy at a depth of $2-3 \mathrm{~km}$, perhaps due to the lower viscosity of magma at this depth permitting a maximum ascent rate (e.g., Burton et al., 2007). There are two main regimes of magma flow, firstly as a result of effusive eruption, in which magma degasses and crystallizes during ascent before erupting, and secondly due to the convective overturn of magma during quiescent degassing (Kazahaya et al., 1994; Beckett et al., 2014) which is required to sustain the persistent degassing flux of Mt. Etna (e.g., Allard, 1997). This flow transports magma from below $3 \mathrm{~km}$ depth (from the volcano summit) to nearsurface, which is the principle pressure regime where sulfur and water exsolution takes place at Mt. Etna (Metrich et al., 2004; Spilliaert et al., 2006; Wallace and Edmonds, 2011). Convective overturn leads to permanent burial of degassed magma in the roots of the plumbing system, revealed as a voluminous plutonic body in seismic tomography observations (Patanè et al., 2006; Díaz-Moreno et al., 2018). We tentatively propose that periods of weak correlation between $\mathrm{SO}_{2}$ flux and tremor, such as that observed in early 2007, are produced when magmatic overturn slows down, and degassing becomes dominated by permeable gas flow from depth. A further related process, which could play a key role, is the level and condition of magma in the conduit, as a lower magma level together with magma viscosity, gas and crystal content may attenuate the tremor amplitude (e.g., Collier et al., 2006). These processes will be investigated in future work through examination of $\mathrm{CO}_{2} / \mathrm{SO}_{2}$ and ground deformation time series. Short-term correlations on the scale of a day between gas flux and tremor during quiescent periods are not observed clearly, perhaps because variations in the continuous degassing process are relatively small compared with the overall degassing rate and fall below measurement noise. Future improvements in the precision and accuracy of $\mathrm{SO}_{2}$ flux quantifications are required to reveal any short-term correlations during passive degassing.

In order to characterize the main oscillations of both intermittent paroxysmal and 2008-2009 eruptive phases, corresponding to the more intense explosive episodes of the study period, an inspection at daylight intraday scale was carried out. Tremor was decomposed to its spectral components between 0.025 and $10.5 \mathrm{~Hz}$ signal, and then each volcanic tremor frequency was compared with $\mathrm{SO}_{2}$ flux using correlation analysis. This decomposition allowed statistical identification on the best correlation between $\mathrm{SO}_{2}$ flux and volcanic tremor frequency, and highlights that in different eruptive contexts the geochemical signal correlated with tremor at different dominant frequencies (Figure 4). We found that $\mathrm{SO}_{2}$ flux correlated strongly with volcanic tremor with high frequencies during the most explosive activity. This is consistent with the observation of coupling via infrasound between explosive volcanic activity and the ground, producing a high frequency tremor source (Matoza and Fee, 2014). In the six case studies investigated here, the first three of them, i.e., those falling within the intermittent paroxysmal phase (Figure 2) showed the highest $\mathrm{SO}_{2}$ flux/tremor correlation coefficients at frequencies of 2.5-6.5 Hz (Table 1; Figure 4). Conversely, the case studies pertaining to the 20082009 eruptive fissure activity displayed the highest correlations at lower frequencies, i.e., from 0.025 to $2.5 \mathrm{~Hz}$ (Table 1; Figure 4). The fact that the two parameters correlated at different tremor frequencies, and that the frequency depended on the intensity of the associated eruptive phenomenon, suggests that on long time scales, some of the signal features could be masked or missed if the RMS is calculated for all frequencies. Falsaperla et al. (2005) analyzed amplitude and frequency content of the seismic 

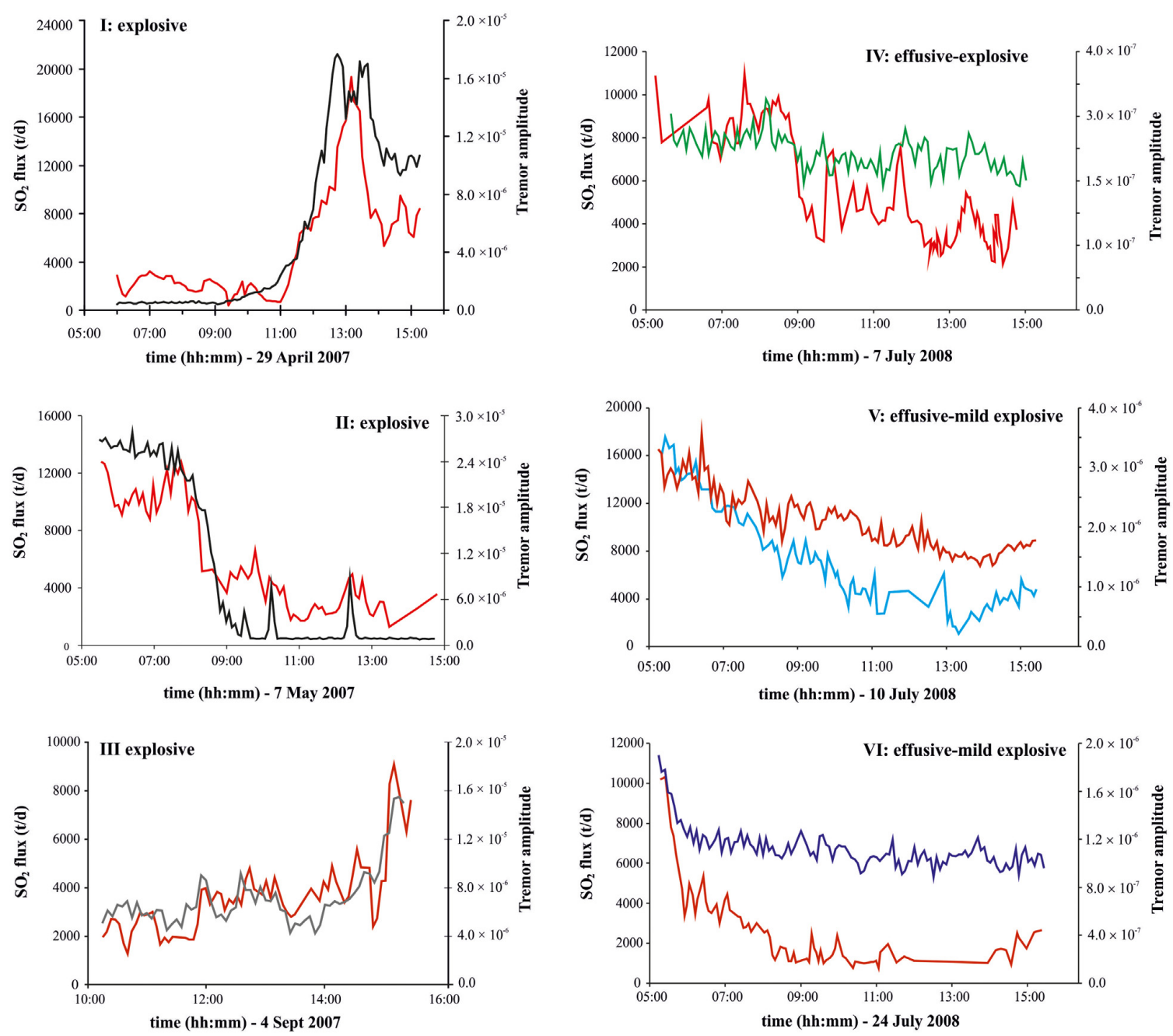

FIGURE 3 | Intraday $\mathrm{SO}_{2}$ flux and volcanic tremor amplitude for the selected case studies (Table 1). In the six cases, tremor mirrored $\mathrm{SO}_{2}$ outgassing in different eruptive style and transition. $\mathrm{SO}_{2}$ flux (red line) was strongly correlated with volcanic tremor at frequency band with max correlation clustered in two groups of high (black line) and medium-low frequency (gray, green, cyan, and blue lines).

signal of the $2001 \mathrm{Mt}$. Etna's flank eruption finding considerable changes in the volcanic tremor associated with different styles of eruptive activity. In particular, they observed that the dominant frequency of the signal decreased from $\sim 5 \mathrm{~Hz}$ to $3 \mathrm{~Hz}$ during lava fountaining, and further decreased to $\sim 2 \mathrm{~Hz}$ during intense lava emissions, supporting the infrasound-coupling hypothesis as the source of seismic tremor during more explosive activity. There were also periods where $\mathrm{SO}_{2}$ flux and tremor appear anticorrelated on short timescale, resulting from time shifts of the two parameters. Shifts were identified in cases 1, 2, and 4, with gas lagging behind seismic energy release. This behavior, which has also been observed on long-time scales by Leonardi et al., 2000b, has been interpreted as due to increasing pressurization of the volcano's shallow feeder system, which simultaneously increases tremor but with a lag time before gas release at the onset of eruptive activity (e.g., Young et al., 2003; Nadeau et al., 2011). A further process might rely on the turbulent magma-flow rate in the upper conduit triggered by gas-slug dynamics during ongoing eruptive events (e.g., Parfitt, 2004) coupled with instability of magma column (Bercovici et al., 2013).

These results underline that though the strong association between magmatic degassing and tremor, several process are involved in generating seismic energy. Their mutual behavior might change depending on the physical mechanism of magma flow regime and gas/melt separation in the conduit, revealing the gas-tremor study puzzling. Although further efforts are required to advance our understating in magmatic degassing - seismic tremor release relationship, the strong correlation observed in this study between the two parameters, indicates that degassing generates seismic tremor, and that gas flux might thereby provide a proxy for eruptive style and intensity and short-term warning for impeding eruptions. 

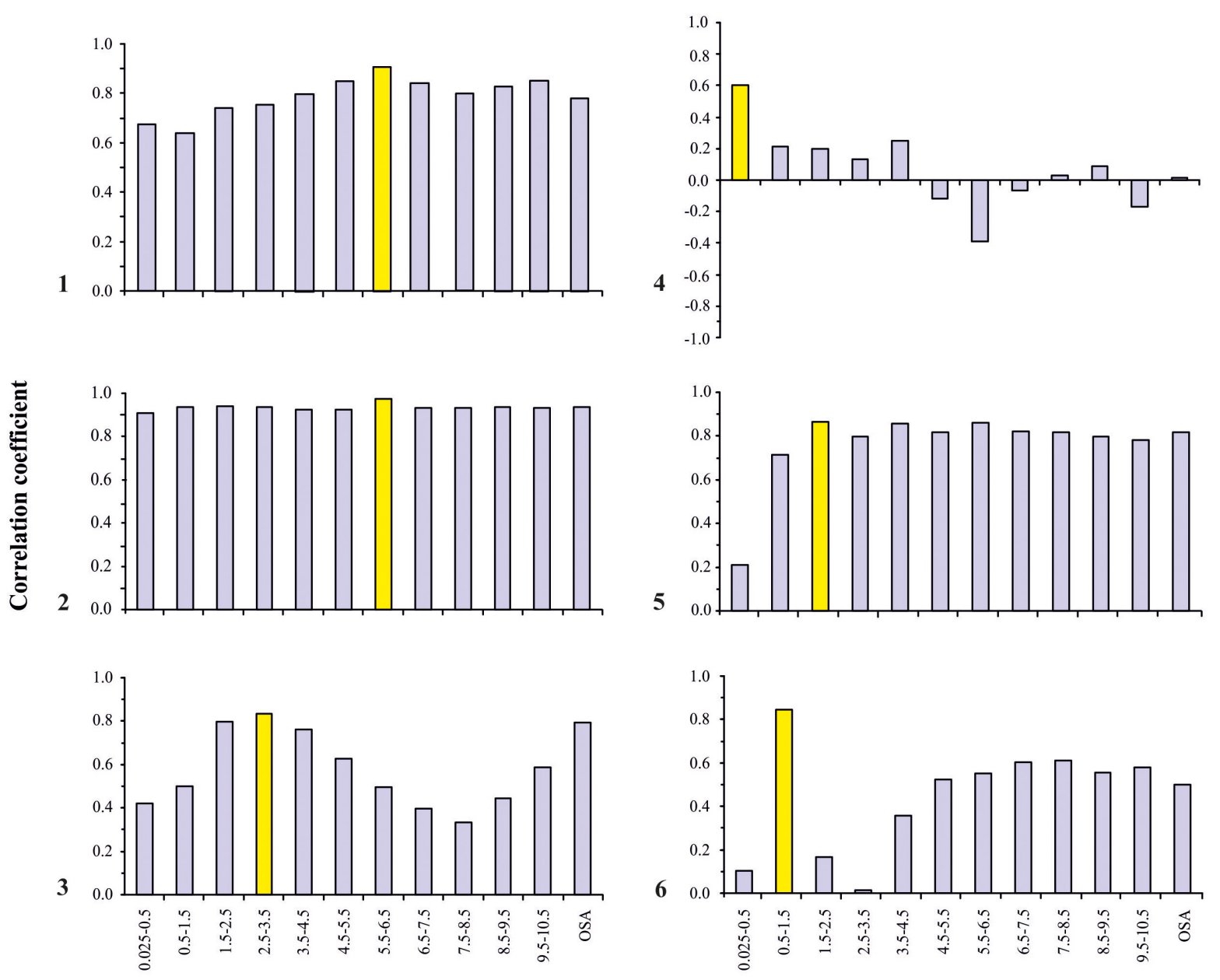

Frequency (Hz)

FIGURE 4 | Correlation coefficient of $\mathrm{SO}_{2}$ flux vs. volcanic tremor in the six intraday case studies investigated at frequency bands between 0.025 and $10.5 \mathrm{~Hz}$ and OSA. Overall, the two parameters show reliable correlation between 0.6 and $0.9 \mathrm{~Hz}$ (Leonardi et al., 2000b). In each of the six histograms, the yellow bin represents the maximum correlation between the $\mathrm{SO}_{2}$ flux and volcanic tremor. In detail, case studies 1,2 , and 5 (except for the frequency below $0.5 \mathrm{~Hz}$ ) show good correlation at almost all frequencies. Case studies 3 and 6 display bimodal distribution of the correlation coefficients with dominant frequencies centered at 3 and $1 \mathrm{~Hz}$ in case study 3 and 6 , respectively. Case study 4 is characterized by both positive and negative correlation coefficient values. The positive maximum value corresponds to below $0.5 \mathrm{~Hz}$. The negative bars indicate the frequencies at which $\mathrm{SO}_{2}$ flux and volcanic tremor anticorrelated

\section{CONCLUSION}

Both explosive and effusive eruptions are believed to be largely controlled by volatile content and magma flow rate (e.g., Woods and Cardoso, 1997), and by their mutual modulation within the shallow conduit (e.g., Jaupart and Vergniolle, 1988). Likewise, seismic tremor varies with volcanic activity and is considered originated by fluids dynamic process in volcanic conduit (e.g., Chouet, 1996). Results achieved in this study provide strong evidence that for extended periods the volcanic tremor and $\mathrm{SO}_{2}$ flux signals on Mt. Etna are strongly correlated. The mutual relationship rely on a physical mechanism of magma flow, which through friction between magma and conduit walls produces a tremor signal with frequency dominated between 0.025 and $2.5 \mathrm{~Hz}$. This magma flow provides the source of $\mathrm{SO}_{2}$ emitted persistently at the summit craters during passive degassing and the eruptive vents during effusive activity, through exsolution and transport of $\mathrm{SO}_{2}$ during magma ascent. We tentatively attribute periods of low correlation between tremor and $\mathrm{SO}_{2}$ flux to a different degassing regime, dominated by fluxing of gas from depth, and this hypothesis will be tested in future work. Our examination of explosive activity demonstrates that the best correlation is achieved between high frequency tremor (2.5-6.5 Hz) and $\mathrm{SO}_{2}$ flux, which we attribute to a process of coupling through infrasound between the explosive activity in the atmosphere and the surface, creating high frequency tremor. Our results underline the clear link between the geochemical and the geophysical signals. Their common behavior during both quiescent and eruptive stages, and during transitions between eruptive regimes, emphasizes that magmatic degassing produces 
volcanic tremor, and that both originate from a common physical mechanism of magma dynamics in the shallow conduit. This study provides a framework for the interpretation of tremor and $\mathrm{SO}_{2}$ degassing to other persistently active basaltic systems worldwide, which will assist in the understanding of the processes and mechanisms controlling unrest and pre-eruptive activity.

\section{AUTHOR CONTRIBUTIONS}

GS and $\mathrm{MB}$ coordinated the research and mainly wrote the manuscript with the substantial, direct, and intellectual contribution to the work from all authors.

\section{REFERENCES}

Aiuppa, A., Burton, M., Caltabiano, T., and Ripepe, M. (2009). “Anti-correlation between gas flux and volcanic tremor on Stromboli volcano," in Proceedings of the Geophysical Research Abstracts 11, EGU2009-13671, EGU General Assembly 2009, Göttingen.

Aiuppa, A., Cannata, A., Cannavò, F., Di Grazia, G., Ferrari, F., Giudice, G., et al. (2010). Patterns in the recent 2007-2008 activity of Mount Etna volcano investigated by integrated geophysical and geochemical observations. Geochem. Geophys. Geosyst. 11:Q09008. doi: 10.1029/2010GC003168

Aiuppa, A., Giudice, G., Gurrieri, S., Liuzzo, M., Burton, M., Caltabiano, T., et al. (2008). Total volatile flux from Mount Etna. Geophys. Res. Lett. 35:L24302. doi: 10.1029/2008GL035871

Aki, K., Fehler, M., and Das, S. (1977). Source mechanism of volcanic tremor: fluid-driven crack models and their application to the 1963 Kilauea eruption. J. Volcanol. Geotherm. Res. 2, 259-287. doi: 10.1016/0377-0273(77)90003-8

Allard, P. (1997). Endogenous magma degassing and storage at Mount Etna. Geophys. Res. Lett. 24, 2219-2222. doi: 10.1029/97GL02101

Allard, P., Burton, M., and Murè, F. (2005). Spectroscopic evidence for a lava fountain driven by previously accumulated magmatic gas. Nature $433,407-410$. doi: $10.1038 /$ nature 03246

Aloisi, M., Bonaccorso, A., Cannavò, F., Gambino, S., Mattia, M., Puglisi, G., et al. (2009). A new dyke intrusion style for the Mount Etna May 2008 eruption modelled through continuous tilt and GPS data. Terra Nova 21, 316-321. doi: 10.1111/j.1365-3121.2009.00889.x

Alparone, S., Andronico, D., Lodato, L., and Sgroi, T. (2003). Relationship between tremor and volcanic activity during the Southeast Crater eruption on Mount Etna in early 2000. J. Geophys. Res. 108:2241. doi: 10.1029/2002JB0 01866

Alparone, S., Behncke, B., Giammanco, S., Neri, M., and Privitera, E. (2005). Paroxysmal summit activity at Mt. Etna (Italy) monitored through continuous soil radon measurements. Geophys. Res. Lett. 32:L16307. doi: 10.1029/ 2005GL023352

Andronico, D., Cristaldi, A., and Scollo, S. (2008). The 4-5 September 2007 lava fountain at South-East Crater of Mt. Etna, Italy. J. Volcanol. Geotherm. Res. 173, 325-328. doi: 10.1016/j.jvolgeores.2008.02.004

Bani, P., and Lardy, M. (2007). Sulphur dioxide emission rates from Yasur volcano, Vanuatu archipelago. Geophys. Res. Lett. 34:L20309. doi: 10.1029/ 2007GL030411

Battaglia, J., Aki, K., and Ferrazzini, V. (2005). Location of tremor sources and estimation of lava output using tremor source amplitude on the Piton de la Fournaise volcano: 2. Estimation of lava output. J. Volcanol. Geotherm. Res. 147, 291-308. doi: 10.1016/j.jvolgeores.2005.04.006

Beckett, F. M., Burton, M., Mader, H. M., Phillips, J. C., Polacci, M., Rust, A. C., et al. (2014). Conduit convection driving persistent degassing at basaltic volcanoes. J. Volcanol. Geotherm. Res. 283, 19-35. doi: 10.1016/j.jvolgeores. 2014.06.006

Behncke, B., Fornaciai, A., Neri, M., Favalli, M., Ganci, G., and Mazzarini, F. (2016). Lidar surveys reveal eruptive volumes and rates at Etna, 2007-2010. Geophys. Res. Lett. 43, 4270-4278. doi: 10.1002/2016GL068495

\section{ACKNOWLEDGMENTS}

We greatly acknowledge F. Murè and V. Longo for their technical assistance in the FLAME network. We thank Dr. L. Spampinato for useful discussions. We are also grateful to the two reviewers for helpful comments and suggestions.

\section{SUPPLEMENTARY MATERIAL}

The Supplementary Material for this article can be found online at: https://www.frontiersin.org/articles/10.3389/feart. 2018.00157/full\#supplementary-material

Benoit, J. P., and McNutt, S. R. (1997). New constraints on source processes of volcanic tremor at Arenal Volcano, Costa Rica, using broadband seismic data. Geophys. Res. Lett. 24, 449-452. doi: 10.1029/97GL00179

Bercovici, D., Jellinek, A. M., Michaut, C., Roman, D. C., and Morse, R. (2013). Volcanic tremors and magma wagging: gas flux interactions and forcing mechanism. Geophys. J. Int. 195, 1001-1022. doi: 10.1093/gji/ ggt277

Bonaccorso, A., Bonforte, A., Calvari, S., Del Negro, C., Di Grazia, G., Ganci, G., et al. (2011a). The initial phases of the 2008-2009 Mount Etna eruption: a multidisciplinary approach for hazard assessment. J. Geophys. Res. 116:B03203. doi: 10.1029/2010JB007906

Bonaccorso, A., Caltabiano, T., Currenti, G., Del Negro, C., Gambino, S., Ganci, G., et al. (2011b). Dynamics of a lava fountain revealed by geophysical, geochemical and thermal satellite measurements: the case of 10 April $2011 \mathrm{Mt}$. Etna eruption. Geophys. Res. Lett. 38:L24307. doi: 10.1029/2011GL049637

Brandsdóttir, B., and Einarsson, P. (1992). "Volcanic tremor and low frequency earthquakes in Iceland," in Volcanic Seismology, eds P. Gasparini, R. Scarpa, and K. Aki (Canberra: IAVCEI), 212-222.

Bruno, N., Caltabiano, T., Grasso, M. F., Porto, M., and Romano, R. (1995). "Studio dell 'emissione di anidride solforosa (SO2) all' Etna - 1993/1994," in ProgettoEtna 1993-1995, eds F. Ferrucci and F. Innocenti (Pisa: Giardini Editore), 29-33.

Bryan, C. J., and Sherburn, S. (2003). Eruption-induced modifications to volcanic seismicity at Ruapehu, New Zealand, and its implications for eruption forecasting. Bull. Volcanol. 65, 30-42. doi: 10.1007/s00445-002-0 236-z

Burton, M., Allard, P., Murè, F., and Oppenheimer, C. (2003). "FTIR remote sensing of fractional magma degassing at Mount Etna, Sicily," in Volcanic Degassing, Vol. 213, eds C. Oppenheimer, D. M. Pyle, and J. Barclay (London: Geological Society Special Publication), 281-293. doi: 10.1144/GSL.SP.2003. 213.01.17

Burton, M., Mader, H. M., and Polacci, M. (2007). The role of gas percolation in quiescent degassing o of persistently active basaltic volcanoes. Earth Planet. Sci. Lett. 264, 46-60. doi: 10.1016/j.epsl.2007.08.028

Burton, M. R., Caltabiano, T., Murè, F., Salerno, G., and Randazzo, D. (2009). SO2 flux from Stromboli during the 2007 eruption: results from the FLAME network and traverse measurements. J. Volcanol. Geotherm. Res. 182, 214-220. doi: 10.1016/j.jvolgeores.2008.11.025

Burton, M. R., Prata, F., and Platt, U. (2015a). Volcanological applications of SO2 cameras. J. Volcanol. Geotherm. Res. 300, 2-6. doi: 10.1016/j.jvolgeores.2014. 09.008

Burton, M. R., Salerno, G. G., D’Auria, L., Caltabiano, T., Murè, F., and Maugeri, R. (2015b). SO2 flux monitoring at Stromboli with the new permanent INGV SO2 Camera system: a comparison with the FLAME network and seismological data. J. Volcanol. Geotherm. Res. 300, 95-102. doi: 10.1016/j.jvolgeores.2015.02.006

Caltabiano, T., Burton, M., Giammanco, S., Allard, P., Bruno, N., Murè, F., et al. (2004). "Volcanic gas emissions from the summit craters and flanks of Mt. Etna, 1987-2000," in Mt. Etna: Volcano Laboratory, Vol. 143, eds A. Bonaccorso, S. Calvari, M. Coltelli, C. Del Negro, and S. Falsaperla (Washington, DC: American Geophysical Union), 111-128. doi: 10.1029/143GM08 
Calvari, S., Inguaggiato, S., Puglisi, G., Ripepe, M., and Rosi, M. (2008). The Stromboli Volcano: An Integrated Study of the 2002-2003 Eruption. Geophysical Monograph Series 182. Washington, DC: American Geophysical Union, doi: 10.1029/GM182

Calvari, S., Salerno, G. G., Spampinato, L., Gouhier, M., La Spina, A., Pecora, E., et al. (2011). An unloading foam model to constrain Etna's 11-13 January 2011 lava fountaining episode. J. Geophys. Res. 116:B11207. doi: 10.1029/ 2011JB008407

Campion, R., Delgado-Granados, H., and Mori, T. (2015). Image-based correction of the light dilution effect for $\mathrm{SO} 2$ camera measurements. J. Volcanol. Geotherm. Res. 300, 48-57. doi: 10.1016/j.jvolgeores.2015.01.004

Cannata, A., Catania, A., Alparone, S., and Gresta, S. (2008). Volcanic tremor at Mt. Etna: inferences on magma dynamics during effusive and explosive activity. J. Volcanol. Geotherm. Res. 178, 19-31. doi: 10.1016/j.jvolgeores.2007.11.027

Cannata, A., Di Grazia, G., Aliotta, M., Cassisi, C., Montalto, P., and Patanè, D. (2013). Monitoring Seismo-volcanic and infrasonic signals at volcanoes: Mt. Etna case study. Pure Appl. Geophys. 170, 1751-1771. doi: 10.1007/s00024-0120634-x

Cannata, A., Di Grazia, G., Giuffrida, M., Gresta, S., Palano, M., Sciotto, M., et al. (2018). Space- time evolution of magma storage and transfer at Mt. Etna volcano (Italy): the 20152016 reawakening of Voragine crater. Geochem. Geophys. Geosys. 19, 471-495. doi: 10.1002/2017GC007296

Cannata, A., Giudice, G., Guerrieri, S., Montalto, P., Alparone, S., Di Grazia, G., et al. (2009a). Relationship between soil CO2 flux and volcanic tremor at Mt. Etna: implications for magma dynamics. Environ. Earth Sci. 61, 477-489. doi: 10.1007/s12665-009-0359-z

Cannata, A., Montalto, P., Privitera, E., Russo, G., and Gresta, S. (2009b). Tracking eruptive phenomena by infrasound: May 13, 2008 eruption at Mt. Etna. Geophys. Res. Lett. 36:L05304. doi: 10.1029/2008GL036738

Chouet, B. (1996). Long-Period volcano seismicity: its source and use in eruption forecasting. Nature 380, 309-316. doi: 10.1038/380309a0

Chouet, B., Koyanagi, R. Y., and Aki, K. (1987). "Origin of volcanic tremor in Hawaii, Part II: theory and discussion," in Volcanism in Hawaii, U.S. Geological Survey Professional Paper, Vol. 1350, eds R. W. Decker, T. L. Wright, and P. H. Stauffer (Washington, DC: US Government Publishing office), 1259-1280.

Collier, L., Neuberg, J., Lensky, N., and Lyakhovsky, V. (2006). Attenuation in gas-charged magma. J. Volcanol. Geotherm. Res. 153, 21-36. doi: 10.1016/j. jvolgeores.2005.08.009

Corsaro, R. A., Andronico, D., Behncke, B., Branca, S., Caltabiano, T., Ciancitto, F., et al. (2017). Monitoring the December 2015 summit eruptions of Mt. Etna (Italy): implications on eruptive dynamics. J. Volcanol. Geotherm. Res. 341, 53-69. doi: 10.1016/j.jvolgeores.2017.04.018

Corsaro, R. A., and Miraglia, L. (2009). Dynamics of magma in the plumbing system of Mt. Etna volcano, Sicily, Italy: a contribution from petrologic data of volcanic erupted from 2007 to 2009. EOS Trans. AGU 90:1690.

Currenti, G., Napoli, R., Di Stefano, A., Greco, F., and Del Negro, C. (2011). 3D integrated geophysical modeling for the 2008 magma intrusion at Etna: constraints on rheology and dike overpressure. Phys. Earth Planet. Int. 185, 44-52. doi: 10.1016/j.pepi.2011.01.002

Davis, J. C. (1986). Statistics and Data analysis in Geology, 2nd Edn. New York, NY: John Wiley \& Sons.

Di Grazia, G., Cannata, A., Montalto, P., Patanè, D., Privitera, E., Zuccarello, L., et al. (2009). A multiparameter approach to volcano monitoring based on $4 \mathrm{D}$ analyses of seismo-volcanic and acoustic signals: the $2008 \mathrm{Mt}$. Etna eruption. Geophys. Res. Lett. 36:L18307. doi: 10.1029/2009GL039567

Di Grazia, G., Falsaperla, S., and Langer, H. (2006). Volcanic tremor location during the 2004 Mount Etna lava effusion. Geophys. Res. Lett. 33:L04304. doi: 10.1029/2005GL025177

Díaz-Moreno, A., Barberi, G., Cocina, O., Koulakov, I., Scarfi, L., Zuccarello, L., et al. (2018). New insights on Mt. Etna's crust and relationship with the regional tectonic framework from joint active and passive P-wave seismic tomography. Surv. Geophys. 39, 57-97. doi: 10.1007/s10712-017-9425-3

Doukas, M. P., and Gerlach, T. M. (1995). "Sulfur dioxide scrubbing during the 1992 eruptions of Crater Peak, Mount Spurr Volcano, Alaska," in The 1992 Eruptions of Crater Peak Vent, Mount Spurr Volcano, Alaska, Vol. 2139, ed. T. E. C. Keith (Reston, VA: U.S. Geological Survey), 47-57.
Edmonds, M., Herd, R. A., Galle, B., and Oppenheimer, C. M. (2003a). Automated, high time- resolution measurements of $\mathrm{SO} 2$ flux at Soufrière Hills Volcano, Montserrat. Bull. Volcanol. 65, 578-586. doi: 10.1007/s00445-003-0286-x

Edmonds, M., Oppenheimer, C., Pyle, D. M., Herd, R. A., and Thompson, G. (2003b). SO2 emissions from Soufrière Hills Volcano and their relationship to conduit permeability, hydrothermal interaction and degassing regime. J. Volcanol. Geotherm. Res. 124, 23-43. doi: 10.1016/S0377-0273(03) 00041-6

Ereditato, D., and Luongo, G. (1994). Volcanic tremor wave field during quiescent and eruptive activity at Mt. Etna (Sicily). J. Volcanol. Geotherm. Res. 61, 239-251. doi: 10.1016/0377-0273(94)90006-X

Falsaperla, S., Alparone, S., D’Amico, S., Di Grazia, G., Ferrari, F., Langer, H., et al. (2005). Volcanic tremor at Mt. Etna, Italy, preceding and accompanying the eruption of July- August, 2001. Pure Appl. Geophys. 162, 1-22. doi: 10.1126/ sciadv.1700219

Fischer, T. P., Morrissey, M. M., Calvache, M. L. V., Gòmez, D. M., Torres, R. C., Stix, J., et al. (1994). Correlations between SO2 flux and long-period seismicity at Galeras volcano. Nature 368, 135-137. doi: 10.1038/368135a0

Gordeev, E. (1993). Modeling of volcanic tremor as explosive point sources in a singled-layered, elastic half-space. J. Geophys. Res. 98, 19687-19703. doi: 10. 1029/93JB00348

Gresta, S., Imposa, S., Patanè, D., and Patanè, G. (1987). Volcanic tremor at Mt. Etna: state-of- the-art and perspectives. Pure Appl. Geophys. 125, 1079-1095. doi: $10.1007 / \mathrm{BF} 00879369$

Gresta, S., Montalto, A., and Patanè, G. (1991). Volcanic tremor at Mount Etna (January 1984-March 1985): its relationship to the eruptive activity and modelling of the summit feeding system. Bull. Volcanol. 53, 309-320. doi: 10.1007/BF00414527

Heliker, C., Kauahikaua, J., Sherrod, D. R., Lisowski, M., and Cervelli, P. (2003). “The rise and fall of Pu'u 'Ô'ô cone, 1983-2002," in The Pu'u 'Ô'ô -Kûpaianaha Eruption of Kîlauea Volcano, Hawai'i: The First 20 Years, Vol. 1676, eds C. Heliker, D. A. Swanson, and T. J. Takahashi (Denver, CO: U.S. Geological Survey Professional Paper), 29-51.

Hibert, C., Mangeney, A., Polacci, M., Di Muro, A., Vergniolle, S., Ferrazzini, V., et al. (2015). Toward continuous quantification of lava extrusion rate: results from the multidisciplinary analysis of the 2 January 2010 eruption of Piton de la Fournaise volcano, La Réunion. J. Geophys. Res. Solid Earth 120, 3026-3047. doi: 10.1002/2014JB011769

James, M. R., Applegarth, L. J., and Pinkerton, H. (2011). Lava channel roofing, overflows, breaches and switching: insights from the 2008-2009 eruption of Mt. Etna. Bull. Volcanol. 74, 107-117. doi: 10.1007/s00445-011-0513-9

Jaupart, C., and Vergniolle, S. (1988). Laboratory models of Hawaiian and Strombolian eruptions. Nature 331, 58-60. doi: 10.1038/331058a0

Johnson, J. H., and Poland, M. P. (2013). Seismic detection of increased degassing before Kîlauea's 2008 summit explosion. Nat. Commun. 4:1668. doi: 10.1038/ ncomms 2703

Kazahaya, K., Shinohara, H., and Saito, G. (1994). Excessive degassing of IzuOshima volcano: magma convection in a conduit. Bull. Volcanol. 56, 207-216. doi: 10.1007/BF00279605

Kazahaya, K., Shinohara, H., Uto, K., Odai, M., Nalkahori, Y., Mori, H., et al. (2004). Gigantic SO2 emission from Miyakejima volcano, Japan, caused by caldera collapse. Geology 32, 425-428. doi: 10.1130/G20399.1

Konstantinou, K. I., and Schlindwein, V. (2002). Nature, wavefield properties and source mechanism of volcanic tremor: a review. J. Volcanol. Geotherm. Res. 119, 161-187. doi: 10.1016/S0377-0273(02)00311-6

Kubotera, A. (1974). "Volcanic tremors at Aso volcano," in Physical Volcanology, Vol. 6, eds L. Civetta, P. Gasparini, G. Luongo, and A. Rapolla (Amsterdam: Elsevier), 29-47. doi: 10.1016/B978-0-444-41141-9.50 008-5

La Spina, A., Burton, M., Allard, P., Alparone, A., and Muré, F. (2015). Open-path FTIR spectroscopy of magma degassing processes during eight lava fountains on Mount Etna. Earth Planet. Sci. Lett. 413, 123-134. doi: 10.1016/j.epsl.2014. 12.038

La Spina, G., Polacci, M., Burton, M., and de’ Michieli Vitturi, M. (2017). Numerical investigation of permeability models for low viscosity magmas: application to the 2007 Stromboli effusive eruption. Earth Planet. Sci. Lett. 473, 279-290. doi: 10.1016/j.epsl.2017.06.013 
Langer, H., Falsaperla, S., Messina, A., Spampinato, S., and Behncke, B. (2010). Detecting imminent eruptive activity at Mt. Etna, Italy, in 2007-2008 through pattern classification of volcanic tremor data J. Volcanol. Geotherm. Res. 200, 1-17. doi: 10.1016/j.jvolgeores.2010. 11.019

Leonardi, S., Gresta, S., and Mulargia, F. (2000a). Cross-correlation between tremor and SO2 flux data from Mount Etna volcano, 1987-1992. Phys. Chem. Earth 25, 737-740. doi: 10.1016/S1464-1895(00)00114-9

Leonardi, S., Gresta, S., and Mulargia, F. (2000b). Searching for a significant correlation between volcanic tremor amplitude and $\mathrm{SO} 2$ emissions at Mount Etna volcano, Sicily. Geophys. J. Int. 141, 832-834. doi: 10.1046/j.1365-246X. 2000.00114.x

Lopez, T., Thomas, H. E., Prata, A. J., Amigo, A., Fee, D., and Moriano, D. (2015). Volcanic plume characteristics determined using an infrared imaging camera. J. Volcanol. Geotherm. Res. 300, 148-166. doi: 10.1016/j.jvolgeores.2014.12.009

Malinconico, L. L. (1979). Fluctuations in SO2 emission during recent eruptions of Etna. Nature 278, 43-45. doi: 10.1038/278043a0

Matoza, R. S., and Fee, D. (2014). Infrasonic component of volcano-seismic eruption tremor. Geophys. Res. Lett. 41, 1964-1970. doi: 10.1002/2014GL059301

McKillup, S., and Dyar, M. D. (2010). Geostatistics Explained. An Introductory Guide for Earth Scientists. Cambridge: Cambridge University Press, 396. doi: 10.1017/CBO9780511807558

McNutt, S. R. (1986). Observations and analysis of B-type earthquakes, explosions, and volcanic tremor at Pavlof Volcano, Alaska. Bull. Seismol. Soc. Am. 76, 153-175.

McNutt, S. R. (1992). "Volcanic tremor," in Encyclopedia of Earth System Science, Vol. 4, ed. W. A. Nierenberg (Cambridge, MA: Academic Press), 417-425.

McNutt, S. R. (2002). "Volcano seismology and monitoring for eruptions," in International Geophysics, International Handbook of Earthquake \& Engineering Seismology, Part B, Vol. 81, eds W. Lee, H. Kanamori, P. Jennings, and C. Kisslinger (New York, NY: Elsevier), 383-406. doi: 10.1016/S0074-6142(02) 80228-5

Metrich, N., Allard, P., Spilliaert, N., Andronico, D., and Burton, M. (2004). 2001 flank eruption of the alkali- and volatile-rich primitive basalt responsible for Mount Etna's evolution in the last three decades. Earth Planet. Sci. Lett. 228, 1-17. doi: 10.1016/j.epsl.2004.09.036

Miller, A. D., Stewart, R. C., White, R. A., Luckett, R., Baptie, B. J., Aspinall, W. P., et al. (1998). Seismicity associated with dome growth and collapse at the Soufriere Hills Volcano, Montserrat. Geophys. Res. Lett. 25, 3401-3404. doi: 10.1029/98GL01778

Miwa, S., Mori, M., and Hibiki, T. (2015). Two-phase flow induced vibration in piping systems. Prog. Nucl. Energy 78, 270-284. doi: 10.1016/j.pnucene.2014. 10.003

Mori, T., and Burton, M. (2006). The SO2 camera: a simple, fast and cheap method for ground- based imaging of $\mathrm{SO} 2$ in volcanic plumes. Geophys. Res. Lett. 33:L24804. doi: 10.1029/2006GL027916

Mori, T., Mori, T., Kazahaya, K., Ohwada, M., Hirabayashi, J., and Yoshikawa, S. (2006). Effect of UV scattering on SO2 emission rate measurements. Geophys. Res. Lett. 33:L17315. doi: 10.1029/2006GL026285

Nadeau, P. A., Palma, J. L., and Waite, G. P. (2011). Linking volcanic tremor, degassing, and eruption dynamics via $\mathrm{SO} 2$ imaging. Geophys. Res. Lett. 38:L01304. doi: 10.1029/2010GL045820

Nadeau, P. A., Werner, C. A., Waite, G. P., Carn, S. A., Brewer, I. D., Elias, T., et al. (2015). Using SO2 camera imagery and seismicity to examine degassing and gas accumulation at Kîlauea Volcano, May 2010. J. Volcanol. Geotherm. Res. 300, 70-80. doi: 10.1016/j.jvolgeores.2014.12.005

Neuberg, J., and Pointer, T. (2000). Effects of volcano-topography on seismic broadband waveforms. Geophys. J. Int. 143, 239-248. doi: 10.1046/j.1365-246x. 2000.00251.x

Omori, F. (1911). The Usu-san eruption and earthquake and elevation phenomena. Bull. Imp. Earthq. Investig. Comm. 5, 1-38.

Palma, J. L., Calder, E. S., Basualto, D., Blake, S., and Rothery, D. A. (2008). Correlations between $\mathrm{SO} 2$ flux, seismicity, and outgassing activity at the open vent of Villarrica volcano, Chile. J. Geophys. Res. 113:B10201. doi: 10.1029/ 2008JB005577

Parfitt, E. A. (2004). A discussion of the mechanisms of explosive basaltic eruptions. J. Volcanol. Geotherm. Res. 134, 77-107. doi: 10.1016/j.jvolgeores.2004.01.002
Patanè, D., Aiuppa, A., Aloisi, M., Behncke, B., Cannata, A., Coltelli, M., et al. (2013). Insights into magma and fluid transfer at Mount Etna by a multiparametric approach: a model of the events leading to the 2011 eruptive cycle. J. Geophys. Res. Solid Earth 118, 3519-3539. doi: 10.1002/jgrb.50248

Patanè, D., Barberi, G., Cocina, O., De Gori, P., and Chiarabba, C. (2006). Timeresolved seismic tomography detects magma intrusions at Mount Etna. Science 313, 821-823. doi: 10.1126/science.1127724

Patanè, D., Di Grazia, G., Cannata, A., Montalto, P., and Boschi, E. (2008). Shallow magma pathway geometry at Mt. Etna volcano. Geochem. Geophys. Geosys. 9:Q12021.

Platt, A., and Stutz, U. (2008). Differential Optical Absorption Spectroscopy Principles and Applications. Heidelberg: Springer, doi: 10.1007/978-3-54075776-4

Poland, M. P., Miklius, A., Sutton, J. A., and Thornber, C. R. (2012). A mantledriven surge in magma supply to Kîlauea volcano during 2003-2007. Nat. Geosci. 5, 295-300. doi: 10.1038/NGEO1426

Salerno, G. G., Burton, M. R., Oppenheimer, C., Caltabiano, T., Randazzo, D., Bruno, N., et al. (2009a). Three-years of SO2 flux measurements of Mt. Etna using an automated UV scanner array: comparison with conventional traverses and uncertainties in flux retrieval. J. Volcanol. Geotherm. Res. 183, 76-83. doi: 10.1016/j.jvolgeores.2009.02.013

Salerno, G. G., Burton, M. R., Oppenheimer, C., Caltabiano, T., Tsanev, V., and Bruno, N. (2009b). Novel retrieval of volcanic SO2 abundance from ultraviolet spectra. J. Volcanol. Geotherm. Res. 181, 141-153. doi: 10.1016/j.jvolgeores. 2009.01.009

Schick, R., and Mugiono, R. (1991). Volcanic Tremor and Magma Flow. Jülich: Forschungszentrum Jülich GmbH, 200.

Shinohara, H. (2005). New technique to estimate volcanic gas composition: plume measurements with a portable multi-sensor system. J. Volcanol. Geotherm. Res. 143, 319-333. doi: 10.1016/j.jvolgeores.2004.12.004

Shinohara, H. (2008). Excess degassing from volcanoes and its role on eruptive and intrusive activity. Rev. Geophys. 46:RG4005. doi: 10.1029/2007RG000244

Spilliaert, N., Allard, P., Mètrich, N., and Sobolev, A. V. (2006). Melt inclusion record of the conditions of ascent, degassing, and extrusion of volatile-rich alkali basalt during the powerful 2002 flank eruption of Mount Etna (Italy). J. Geophys. Res. 111:B04203. doi: 10.1029/2005JB003934

Steffke, A. M., Harris, A. J. L., Burton, M., Caltabiano, T., and Salerno, G. G. (2011). Coupled use of COSPEC and satellite measurements to define the volumetric balance during effusive eruptions at Mt. Etna, Italy. J. Volcanol. Geotherm. Res. 205, 47-53. doi: 10.1016/j.jvolgeores.2010.06.004

Steinberg, G. S., and Steinberg, A. S. (1975). On possible causes of volcanic tremor. J. Geophys. Res. 80, 1600-1604. doi: 10.1029/JB080i011p01600

Sutton, A. J., Elias, T., Gerlach, T. M., and Stokes, J. B. (2001). Implications for eruptive processes as indicated by sulfur dioxide emission from Kîlauea Volcano, Hawai'i, 1979-1997. J. Volcanol. Geotherm. Res. 108, 283-302. doi: 10.1016/S0377-0273(00)00291-2

Swan, A. R. H., and Sandilands, M. (1995). Introduction to Geological Data analysis. Hoboken, NJ: Blackwell Science.

Taquet, N., Meza Hernández, I., Stremme, W., Bezanilla, A., Grutter, M., Campion, R., et al. (2017). Continuous measurements of SiF4 and SO2 by thermal emission spectroscopy: insight from a 6-month survey at the Popocatépetl volcano. J. Volcanol. Geotherm. Res. 341, 255-268. doi: 10.1016/ j.jvolgeores.2017.05.009

Thompson, G., McNutt, S. R., and Tytgat, G. (2002). Three distinct regimes of volcanic tremor associated with the eruption of Shishaldin Volcano, Alaska 1999. Bull. Volcanol. 64, 535-547. doi: 10.1007/s00445-002-0228-z

Vargas-Bracamontes, D. M., Nava, A. F., and Reyes-Dávila, G. A. (2009). Timescale wavelet patterns related to the 1998-1999 eruptions of the Colima volcano, and their possible implications for eruption forecasting. J. Volcanol. Geotherm. Res. 184, 271-284. doi: 10.1016/j.jvolgeores.2009.01.025

Voight, B., Sparks, R. S. J., Miller, A. D., Stewart, R. C., Hoblitt, R. P., Clarke, A., et al. (1999). Magma flow instability and cyclic activity at Soufriere Hills volcano, Montserrat, British West Indies. Science 283, 1138-1142. doi: 10.1126/ science.283.5405.1138

Wallace, P. J., and Edmonds, M. (2011). "The sulfur budget in magmas: evidence from melt inclusions, submarine glasses, and volcanic gas emissions," in Reviews in Mineralogy and Geochemistry, Vol. 73, eds H. Behrens and J. D. Webster (Chantilly, VA: Mineralogical Society of America), 215-246. 
Wallace, P. J., and Gerlach, T. M. (1994). Magmatic vapor source for sulfur dioxide released during volcanic eruptions: evidence from Mount Pinatubo. Science 265, 497-499. doi: 10.1126/science.265.5171.497

Watson, I. M., Oppenheimer, C., Voight, B., Francis, P. W., Clarke, A., Stix, J., et al. (2000). The relationship between degassing and ground deformation at Soufriere Hills Volcano, Montserrat. J. Volcanol. Geotherm. Res. 98, 117-126. doi: 10.1016/S0377-0273(99)00187-0

Williams-Jones, G., Stix, J., Heiligmann, M., Barquero, J., Fernandez, E., and Gonzalez, E. D. (2001). A model of degassing and seismicity at Arenal volcano, Costa Rica. J. Volcanol. Geotherm. Res. 108, 121-139. doi: 10.1016/S03770273(00)00281-X

Williams-Jones, G., Stix, J., and Hickson, C. (2008). The COSPEC Cookbook: Making SO2 Measurements at Active Volcanoes. Rome: IAVCEI, 1. doi: 10. 13140/RG.2.2.13728.99845

Woods, A. W., and Cardoso, S. S. S. (1997). Triggering basaltic volcanic eruptions by bubble-melt separation. Nature 385, 518-520. doi: 10.1038/385518a0

Young, S. R., Francis, P. W., Barclay, J., Casadevall, T. J., Gardner, C. A., Darroux, B., et al. (1998). Monitoring SO2 emissions at the Soufriere Hills Volcano: implications for changes in eruptive conditions. Geophys. Res. Lett. 25, 3681-3684. doi: 10.1029/98GL01406

Young, S. R., Voight, B., and Duffell, H. J. (2003). Magma extrusion dynamics revealed by high- frequency gas monitoring at Soufrière Hills volcano,
Montserrat. Geol. Soc. Spec. Publ. 213, 219-230. doi: 10.1144/GSL.SP.2003.213. 01.13

Zar, J. H. (1972). Significance testing of the spearman rank correlation coefficient. J. Am. Stat. Assoc. 67, 578-580. doi: 10.1080/01621459.1972.10481251

Zobin, V. M. (2003). Introduction to Volcanic Seismology (Developments in Volcanology; 6). Amsterdam: Elsevier Science.

Zuccarello, L., Burton, M. R., Saccorotti, G., Bean, C. J., and Patanè, D. (2013) The coupling between very long period seismic events, volcanic tremor, and degassing rates at Mount Etna volcano. J. Geophys. Res. Solid Earth 118, 4910-4921. doi: 10.1002/jgrb.50363

Conflict of Interest Statement: The authors declare that the research was conducted in the absence of any commercial or financial relationships that could be construed as a potential conflict of interest.

Copyright (c) 2018 Salerno, Burton, Di Grazia, Caltabiano and Oppenheimer. This is an open-access article distributed under the terms of the Creative Commons Attribution License (CC BY). The use, distribution or reproduction in other forums is permitted, provided the original author(s) and the copyright owner(s) are credited and that the original publication in this journal is cited, in accordance with accepted academic practice. No use, distribution or reproduction is permitted which does not comply with these terms. 